\title{
MOTIVASI ATLET CLUB RENANG DI KABUPATEN BADUNG DALAM MENJAGA KEBUGARAN JASMANI PADA MASA PANDEMI COVID-19
}

\author{
I Putu Putra Yasa ${ }^{1}$, I.W. Artanayasa ${ }^{2}$, I.G. Suwiwa ${ }^{3}$ \\ ${ }^{123}$ Jurusan Pendidikan Olahraga, Fakultas Olahraga dan Kesehatan \\ Universitas Pendidikan Ganesha \\ Email : putrayasa191097@gmail.com, wayan.artanayasa@undiksha.ac.id, \\ suwiwagede@undiksha.ac.id
}

\begin{abstract}
ABSTRAK
Penelitian ini bertujuan untuk mengetahui motivasi atlet club renang di kabupaten Badung dalam menjaga kebugaran jasmani pada masa pandemi covid-19. Jenis penelitian ini merupakan penelitian deskriptif kuantitatif dengan jenis survei. Populasi pada penelitian ini adalah Bali Pari Swimming Club, Bali Pari Fins Swimming Club, Taman Tirta Swimming Club dengan jumlah 128 orang, dan sampel pada penelitian ini adalah $25 \%$ dari populasi yaitu berjumlah 32 orang. Pengambilan sampel menggunakan non random sampling yaitu quota sampling. Analisis data menggunakan statistik deskriptif kuantitatif dengan katagori interval. Hasil dari penelitian motivasi atlet club renang di kabupaten Badung dalam menjaga kebugaran jasmani pada masa pandemi covid-19 pada faktor intrinsik yaitu 83 dan pada faktor ekstrinsik mendapat skor 81. Dari kedua faktor tersebut motivasi atlet club renang di Kabupaten Badung dalam menjaga kebugaran jasmani pada masa pandemi covid-19 mendapat skor 82 dalam sekala penelitian katagori sangat tinggi. Saran dari peneliti untuk atlet agar menjadi lebih termotivasi dalam menjaga kebugaran jasmani meskipun ditengah pandemi harus berusaha mencari untuk meningkatkan kebugaran jasmani pada masa pandemi covid-19..
\end{abstract}

Kata kunci: Motivasi, Pandemi covid-19, Kebugaran Jasmani.

\begin{abstract}
This study aims to determine the motivation of swimming club athletes in Badung Regency in maintaining physical fitness during the Covid-19 pandemic. This type of research was a quantitative descriptive study with the type of survey. The population of this study was the Bali Pari Swimming Club, Bali Pari Fins Swimming Club, Taman Tirta Swimming Club with a total of 128 people, and the sample in this study was $25 \%$ of the population, amounting to 32 people. Sampling using non-random sampling, namely quota sampling. Data analysis used quantitative descriptive statistics with interval categories. The result of this research on the motivation of swimming club athletes in Badung Regency in maintaining physical fitness during the Covid-19 pandemic on intrinsic factors were 81 and on extrinsic factors got a score of 82. From these two factors, the motivation of swimming club athletes in Badung Regency in maintaining physical fitness during the Covid-19 pandemic got a score of 82 which at the category interval was declared good. The suggestion from researcher for athletes to be more motivated in
\end{abstract}


maintaining physical fitness even in the midst of a pandemic, they must try to find ways to improve physical fitness during the Covid-19 pandemic.

Keywords: Motivation, Covid-19 Pandemic, Physical Fitness.

\section{PENDAHULUAN}

Pendidikan Merupakan Suatu Proses Yang Mencakup Tiga Dimensi, Individu, Masyarakat Atau Komunitas Nasional Dari Individu Tersebut, Dan Seluruh Kandungan Realitas, Baik Material Maupun Spiritual Yang Memainkan Peranan Dalam Menentukan Sifat, Nasib, Bentuk Manusia Maupun Masyarakat (Nurkholis, 2013).

Di era modern ini pendidikan semakin lama semakin dituntut untuk membenahi diri. Generasi muda seakan-akan diharuskan untuk mempunyai pendidikan yang berkualitas yang sesuai dengan kemajuan ilmu pengetahuan dan teknologi. Peran pendidikan sangat berpengaruh dalam pembentukan jasmani, akal, dan akhlak seseorang sejak dilahirkan hingga dia mati, dimana pendidikan tersebut dapat bermanfaat di kemudian hari. Menurut UU Tahun 2003 Nomor 20 tentang SISDIKNAS mengemukakan bahwa: Pendidikan adalah usaha sadar dan terencana untuk mewujudkan suasana belajar dan proses pembelajaran agar peserta didik secara aktif mengembangkan potensi dirinya untuk memiliki kekuatan spiritual keagamaan, pengendalian diri, kepribadian, kecerdasan, akhlak mulia, serta keterampilan yang diperlukan dirinya dan masyarakat.

Kristiyanto (2012:173) berpendapat pula bahwa perkembangan ilmu dan teknologi keolahragaan di Indonesia sebenarnya cukup pesat, namun kepesatan yang terjadi tidak sebanding dengan pemanfaatannya pada tataran praktis. Para pelatih olahraga dilapangan kurang familiar dengan bentuk-bentuk piranti lunak (software) maupun piranti keras (hardware) teknologi keolahragaan yang Jurnal Terapan IImu Keolahragaan 2016 Vol.01 No.01 Halaman 6-11 Rubiansyah, A., Rusdiana, A.,Mulyana,B.R. 7 sebenarnya berguna untuk mengembangkan prestasi atlet secara efektif. Untuk membangun olahraga renang agar lebih baik kedepannya diperlukan rencana yang teratur dengan baik dengan tujuan yang jelas dan terarah.untuk membantu prestasi agar maksimal ada beberapa aspek yang di perlukan dalam membina olahraga renang diantaranya aspek fisik, aspek teknik, aspek taktik, dan latihan mental. (Harsono, 1988:100) (Rubiansyah, 2017).

Melihat pernyataan di atas mengenai pengertian pendidikan, maka Pendidikan Jasmani, Olahraga, dan Kesehatan (PJOK) mempunyai arti penting dalam proses pembangunan bangsa, karena merupakan bagian integral dari sistem pendidikan secara keseluruhan. Menurut Abduljabar \& Yudiana (dalam Ardha, 2013: 53) "Pendidikan Jasmani, Olahraga, dan Kesehatan adalah suatu mata pelajaran yang menempatkan siswa belajar tentang semua keuntungan yang diperoleh dan pembiasaan gaya hidup aktif secara fisik dan keterampilan serta pengetahuan tentang aktivitas jasmani dan kepuasan beraktivitas jasmani dalam kehidupan". Pada pelaksanaannya PJOK merupakan sebuah investasi jangka panjang dalam upaya pembinaan mutu sumber daya manusia Indonesia. Hasil yang diharapkan itu akan dicapai dalam jangka yang cukup lama. Sebagai bagian dari pendidikan, kita berharap PJOK di lembaga pendidikan formal dapat berkembang lebih pesat lagi agar mampu menjadi landasan pembinaan keolahragaan nasional. Untuk itu, pembentukan sikap dan pembangkitan motivasi mulai dilaksanakan pada setiap jenjang pendidikan formal (Aritianto, 2015).

Pesatnya kemajuan ilmu pengetahuan dan teknologi membuat kemajuan dan perkembangan olahraga renang semakin pesat. Salah satunya pada saat kita melakukan gerakan pada olahraga renang yang baik harus bisa dijelaskan 
berdasarkan ilmu mekanika. Tiga hal yang harus dikuasai sebelum mempelajari gaya dalam olahrag renang diantaranya bernafas, mengapung dan meluncur. Mengapung merupakan salah satu mekanisme yang harus diperhatikan dalam olahraga renang (Sunandarti, 2017).

Mata pelajaran pendidikan jasmani adalah salah satu mata pelajaran yang cenderung membutuhkan keterampilan psikomotor untuk menguasai semua aspekaspek yang akan diajarkan atau di latih, salah satunya adalah aspek aquatik (aktifitas air). Aktifitas air yang di ajarkan adalah, renag gaya bebas, renang gaya dada, renang gaya punggung dan renang gaya kupu-kupu. Dalam hal ini guru harus menjelaskan dan mendemonstrasikan gayagaya tersebut, sehingga siswa maupun mahasiswa mudah mengerti dan mudah untuk mempelajarinya (Malik, 2015).

Kegiatan renang adalah gerakan saat kita berpindah dari satu tempat ke tempat lainnya di dalam air, baik di sungai, laut ataupun kolam renang, bahkan di dalam bak mandi kamu, kalau bak mandi kamu memang luas (Husen, 2013:1). Secara lebih spesifik, olahraga renang merupakan salah satu cabang olahraga air yang menuntut kinerja otot yang kompleks. Dalam melakukan gerakan gaya seperti gaya bebas, gaya punggung, gaya dada dan gaya kupu-kupu hampir seluruh komponen bergerak (Sriningsih, 2017). Sedangkan menurut penulis olahraga renang merupakan olahraga yang dilakukan di air dengan melakukan gerakan atau gaya tertentu diantaranya gaya kupu, gaya punggung, gaya dada dan gaya bebas (Priana, 2019).

Olahraga renang merupakan aktivitas fisik yang dapat membantu mengoptimalkan perkembangan tubuh melalui gerakangerakan yang didasari dengan gerak otot. Karakteristik olahraga secara langsung berkaitan dengan ciri-ciri perilaku manusia dan dengan berbagai macam kegiatan di masyarakat. Salah satu tujuan berolahraga yaitu untuk meningkatkan kesegaran jasmani. Dewasa ini kesadaran masyarakat untuk melakukan olahraga semakin tinggi, salah satunya cabang olahraga renang. Renang sangat penting bagi setiap individu karena dapat menyelamatkan diri sendiri ketika berada di air (Wicaksono, 2017).

Renang bisa dilakukan semua
kalangan umur baik itu anak-
anak,remaja,dewasa dan orang tua.1
Renang menjadi salah satu dari berbagai macam olahraga yang paling digemari di Indonesia. Berenang memerlukan koordinasi dari sebagian besar anggota gerak ekstremitas atas dan bawah. Namun olahraga renang juga dapat menyebabkan kram otot, apabila tidak dilakukan secara benar. Kram otot dapat terjadi dikarenakan berbagai faktor seperti intensitas latihan berlebih, pemanasan fisik yang tidak optimal atau bisa dikarenakan resiko dari gaya berenang (Baskoro, 2018).

Prestasi olahraga renang secara umum menuntut diterapkannya prinsipprinsip latihan agar prestasi olahraga renang dapat meningkat, latihan haruslah berpedoman pada teori serta prinsip latihan yang benar dan sistimatis karena apa bila hal tersebut tidak dilakukan maka prestasi pun sulit dicapai. Olahraga prestasi adalah Olahraga yang membina dan mengembangkan olahragawan secara terencana, berjenjang, dan berkelanjutan melalui kompetisi untuk mencapai prestasi dengan dukungan ilmu pengetahuan dan teknologi keolahragaan. Untuk mewujudkan tercapainya perenang-perenang yang memiliki kemampuan melakukan berbagai aktifitas fisik dalam latihan diperlukan pelatih renang yang memiliki kreativitas dan mengoptimalkan segala kemampuan melalui proses melatih renang dalam program pembinaan prestasi olahraga renang itu sendiri (Ishak, 2018).

Renang merupakan olahraga yang dikenal sudah sejak lama yang banyak memberikan manfaat baik se-cara fisik maupun emosional. Manfaat dari renang tersebut antara lain, untuk keselamatan diri, meningkatkan kebu-garan jasmani, rehabilitasi, dan presta-si. Selain itu renang merupakan olah-raga yang melombakan 
kecepatan atlet renang dalam kemampuan berenang. Perenang yang memenangkan lomba renang merupakan perenang yang menyelesaikan jarak lintasan tercepat untuk meningkatkan suatu prestasi olahraga, perlu memperhati-kan beberapa aspek, aspekaspek tersebut adalah aspek fisik, aspek teknik, aspek taktik, dan aspek psikis (mental) (Prasetyo, 2017).

Dalam kehidupan moderen sekarang ini manusia tidak bisa dipisahkan dari kegiatan olahraga, baik untuk meningkatkan prestasi maupun kebutuhan dalam menjaga kondisi tubuh agar tetap sehat dan bugar. Kebugaran jasmani merupakan modal dasar bagi seseorang melakukan aktivitas fisik secara berulang-ulang dalam relative lama tanpa menimbulkan kelelahan. Aktivitas olahraga sangat mempengaruhi kebugaran jasmani seseorang, aktivitas olahraga memberikan kontribusi langsung pada komponen kebugaran jasmani. Menurut Santoso Giriwijoyo: 2005 (dalam Gilang Okta Prativi dkk: 2013) dari sudut ilmu faal olahraga, olahraga adalah serangkaian gerak raga yang teratur dan terencana yang dilakukan seseorang dengan sadar untuk meningkatkan kemampuan fungsionalnya, sesuai dengan tujuannya melakukan olahraga.

Menurut Suroto (2004: 2)

menyatakan bahwa kebugaran jasmani merupakan kemampuan atau kesanggupan seseorang untuk melakukan aktivitas atau kegiatan dengan daya kerja tinggi dengan tanpa mengalami kelelahan yang berarti atau berlebihan. Menurut Safrit ( dalam arma abdoellah : 2005:47) menyatakan bahwa ada dua definisi yang bisa digunakan, dari sudut pandang fisiologis kebugaran jasmani adalah kapasitas untuk dapat menyesuaikan diri terhadap latihan yang melelahkan dan pulih dari latihan tersebut.

Jadi dapat disimpulkan kebugaran jasmani merupakan kemampuan seseorang melakukan aktivitas sehari-hari secara efisien tanpa menimbulkan kelelahan yang berlebihan sehingga dapat menyesuaikan fungsi alat-alat tubuhnya dan masih dapat menikmati waktu luang.

Secara singkat dapat dikatakan seorang yang aktif berolahraga atau rajin melakukan aktivitas jasmani, memperoleh berbagai manfaat bagi kesehatan. Karena dengan olahraga badan tetap bugar, metabolism tubuh dan peredaran darah lancar, hal itulah mafaat terbesar yang diperoleh dari latihan kebugaran secara teratur, baik dan benar.

Dunia pendidikan menghadapi permasalahan yang cukup komplek dimasa pandemi covid-19. Serangan virus yang hingga kini belum ditemukan vaksinnya tersebut berdampak pada penyelenggaraan pembelajaran pada semua jenjang pendidikan. Jenjang perguruan tinggi dan segaian sekolah menengah yang sudah terbiasa menerapkan pembelajaran online tidak mengalami banyak kendala dalam menghadapi pandemi covid-19, tidak demikian dengan jenjang pendidikan dasar (handphone) ke sekolah atau ke ruang kelas dilarang.

Pembelajaran online di dimasa pandemi adalah bagian dari upaya meningkatkan kewaspadaan terhadap penyebaran virus covid-19 Nuryana 2020 (dalam Herlina, Maman Suherman, 2020:2). Pembelajaran online pada masa pendidikan formal juga merupakan upaya nyata yang dilakukan pemerintah untuk memutuskan mata rantai penyebaran covid-19 (Kementrian Pendidikan dan Kebudayaan Republik Indonesia 2020). Meskipun penyebaran virus di Indonesia yang hingga bulan Juli 2020 belum menunjukkan penurunan namun sumbangan dunia pendidikan melalui "pemaksaan" pembelajaran online memiliki peranan penting dalam mendukung upaya pemerintah dengan seluruh bangsa untuk menahan laju pertambahan jumblah penderitaan dan korban covid-19. 
Efektivitas pembelajaran merupakan salah satu standart mutu pendidikan dan sering kali diukur dengan tercapainya tujuan, atau dapat juga diartikan sebagai ketepatan dalam mengelola suatu situasi, Efektivitas ialah suatu pemanfaatan sarana prasarana, sumber, daya dalam jumlah tertentu yang sebelumnya telah ditetapkan untuk menghasilkan sejumlah barang atau jasa kegiatan yang akan dijalankan oleh seseorang, Dewasa ini masyarakat dunia tengah diresahkan dengan adanya wabah Corona Virus Disease (COVID-19) yang menjadi sebuah pandemi. Seluruh dunia kini disibukkan dengan berbagai upaya pencegahan COVID-19 untuk menahan lonjakan pasien positif karena hingga saat ini masih belum ditemukan obat maupun vaksinnya. Selain itu, dengan adanya virus COVID-19 pemerintah membuat beberapa kebijakan untuk menghentikan penyebaran wabah ini, seperti melakukan lockdown didaerah yang sudah termasuk kedalam zona merah penyebaran virus secara kontak fisik.

Pada masa pandemi covid-19 ini bisa mempengaruhi jasmani atlet-alet renang pada club renang di kabupaten Badung untuk itu para atlet tersebut perlu menjaga kebugaran jasmani dengan beraktifitas namun dengan keterbatasan dalam melakukan aktifitas jasmani maka peneliti bertujuan ingen mengetahui motivasi atlet club renang di kabupaten Badung dalam menjaga kebugaran jasmani pada masa pandemi covid-19.

\section{METODE PENELITIAN}

Teknik analisis data yang digunakan adalah teknik analisis data deskriptif dengan presentase dari jawaban atlet. Jawaban diberikan atlet bermacammacam karena setiap individu memiliki pendapat yang berbeda-beda. Dalam hal ini, data dari penelitian akan dianalisis menggunakan teknik statistik deskriptif dengan presentase, yaitu data dari angket yang berhasil dikumpulkan kemudian dianalisis dengan menggunakan sekala penilaian katagori. Analisi tersebut untuk mengetahui motivasi atlet club renang di kabupaten Badung dalam menjaga kebugaran jasmani pada club renang di kabupaten badung.

Instrument yang digunakan berupa angket terdiri dari pernyataan positif dan negatif, tingkat kesetujuan responden diklasifikasi sebagai berikut :

Tabel 1. Sekala Penilaian atau Katagori

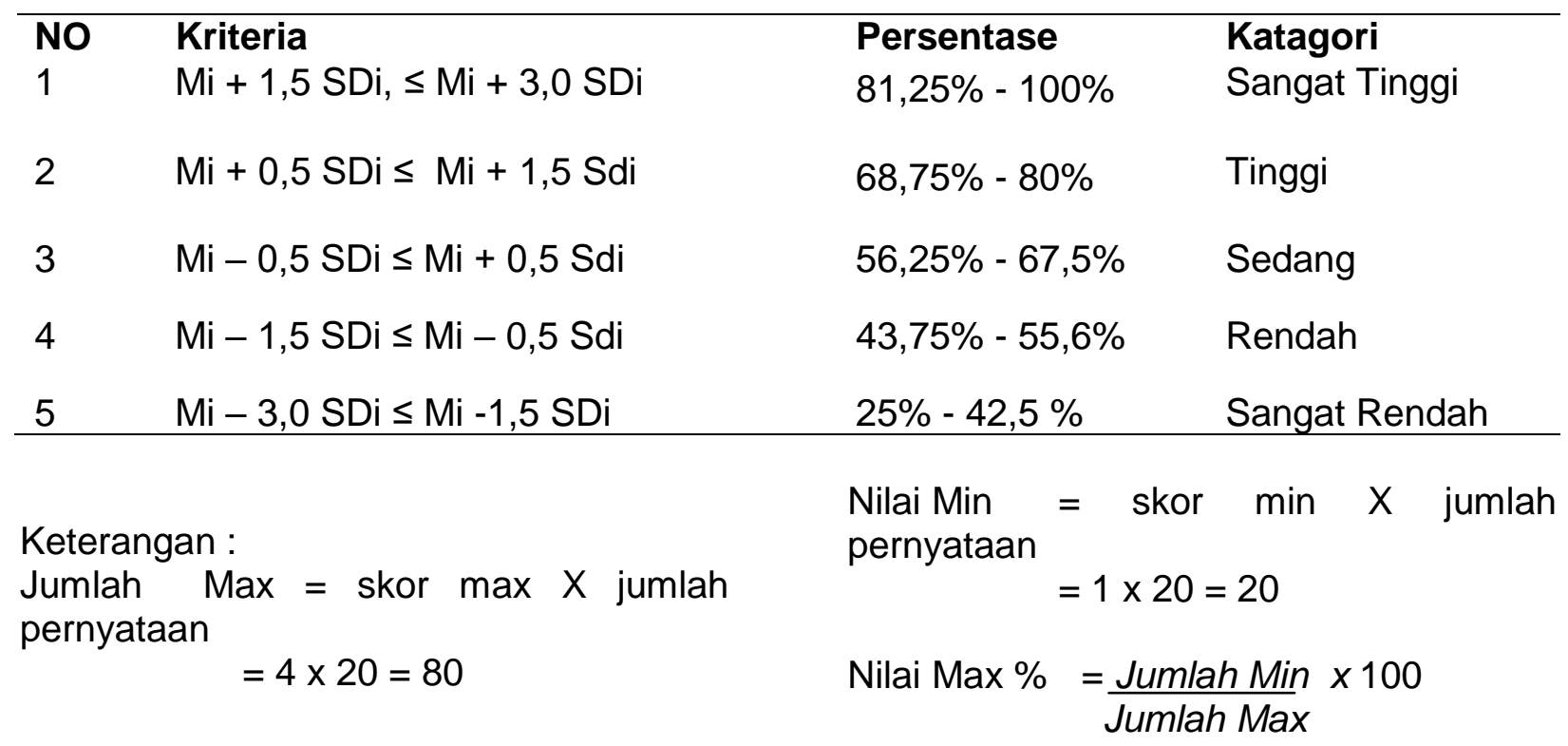




$$
=\frac{20}{80} \times 100
$$

$$
=25 \%
$$

Mi

$$
=1 / 2 \times \text { (nilai } \max +\text { nilai }
$$

$\min$ )

$$
\begin{aligned}
& =1 / 2 \times 125 \\
& =62,5
\end{aligned}
$$

SDi

$$
=1 / 6 \times \text { (nilai max }- \text { nilai }
$$

$\min$ )

$$
\begin{aligned}
& =1 / 6 \times 75 \\
& =12,5
\end{aligned}
$$

Untuk memperoleh dan mengetahui seberapa besar motivasi atlet club renang di kabupaten badung dalam menjaga kebugaran jasmani pada masa pandemi covid-19 ditentukan dengan penghintungan skor dari indikator motivasi intrinsik dan ekstrinsik dengan menggunakan rumus sebagai berikut.

$$
=\quad \mathrm{X} 1 \times \mathrm{X} 2
$$

2

Keterangan :

$\mathrm{X} 1=$ Nilai persentase motivasi intrinsik

$\mathrm{X} 2=$ Nilai persentase motivasi ekstrinsik

\section{HASIL DAN PEMBAHASAN}

\section{Hasil Penelitian}

Data hasil penelitian motivasi atlet Club Renang di Kabupaten Badung dalam menjaga kebugaran jasmani mereka pada masa pandemi covid-19 ini menggunakan teknik statistik deskriptif yang menggunakan perhitungan persentase. Penelitian ini

\begin{tabular}{|c|c|c|c|c|c|c|c|c|c|}
\hline \multirow[t]{2}{*}{ No } & \multirow[t]{2}{*}{ Pernyataan } & \multicolumn{3}{|c|}{$\begin{array}{l}\text { Tanggapan } \\
\text { Responden }\end{array}$} & $\mathbf{N}$ & \multirow[t]{2}{*}{$\begin{array}{l}\text { Rata- } \\
\text { Rata }\end{array}$} & \multirow[t]{2}{*}{ Persentase } & \multicolumn{2}{|c|}{ Kategori } \\
\hline & & SS & $\mathbf{S}$ & TS & STS & & & & \\
\hline 1 & $\begin{array}{lr}\text { Saya } & \text { butuh } \\
\text { berolahraga pada } \\
\text { masa pandemi } \\
\text { covid-19. }\end{array}$ & 16 & 16 & 0 & 0 & 32 & $88 \%$ & 88 & $\begin{array}{l}\text { Sangat } \\
\text { Tinggi }\end{array}$ \\
\hline 2 & $\begin{array}{l}\text { Saya ingin } \\
\text { melakukan } \\
\text { aktivitas jasmani } \\
\text { dengan mudah. }\end{array}$ & 12 & 20 & 0 & 0 & 32 & $84 \%$ & 84 & $\begin{array}{l}\text { Sangat } \\
\text { Tinggi }\end{array}$ \\
\hline 3 & $\begin{array}{l}\text { Aktivitas jasmani } \\
\text { merupakan } \\
\text { aktivitas yang } \\
\text { menjenuhkan. }\end{array}$ & 6 & 24 & 2 & 0 & 32 & $78 \%$ & 78 & $\begin{array}{l}\text { Sangat } \\
\text { Tinggi }\end{array}$ \\
\hline 4 & $\begin{array}{l}\text { Aktivitas jasmani } \\
\text { memberikan hal } \\
\text { yang positif pada } \\
\text { diri saya }\end{array}$ & 18 & 3 & 0 & 0 & 32 & $89 \%$ & 89.1 & $\begin{array}{l}\text { Sangat } \\
\text { Tinggi }\end{array}$ \\
\hline
\end{tabular}
mengkatagorikan data menjadi 5 katagori, yaitu : sangat baik, baik, cukup baik, kurang baik, dan sangat kurang baik. Perhitungan katagori tersebut dibuat berdasarkan nilai rata-rata dan standar devisiasi yang merupakan hasil dari perhitungan deskriptif yang telah dilakukan sebelumnya.

Tabel 2. Analisis Pernyataan 
Jurnal Ilmu Keolahragaan Undiksha

p-ISSN : 2613-9693 | e-ISSN : 2613-9685

Volume 8 Nomor 1 Tahun 2020

\begin{tabular}{|c|c|c|c|c|c|c|c|c|c|}
\hline \multirow[t]{2}{*}{ No } & \multirow[t]{2}{*}{ Pernyataan } & \multicolumn{3}{|c|}{$\begin{array}{l}\text { Tanggapan } \\
\text { Responden }\end{array}$} & \multirow{2}{*}{$\begin{array}{l}\mathbf{N} \\
\text { STS }\end{array}$} & \multirow[t]{2}{*}{$\begin{array}{l}\text { Rata- } \\
\text { Rata }\end{array}$} & \multirow[t]{2}{*}{ Persentase } & \multicolumn{2}{|c|}{ Kategori } \\
\hline & & SS & $\mathrm{S}$ & TS & & & & & \\
\hline 5 & $\begin{array}{l}\text { Saya tertarik untuk } \\
\text { memperhatikan } \\
\text { contoh yang } \\
\text { diberikan } \quad \text { oleh } \\
\text { pelatih. }\end{array}$ & 14 & 18 & 0 & 0 & 32 & $85 \%$ & 85.2 & $\begin{array}{l}\text { Sangat } \\
\text { Tinggi }\end{array}$ \\
\hline 6 & $\begin{array}{l}\text { Saya tertarik untuk } \\
\text { melakukan } \\
\text { aktivitas jasmani } \\
\text { yang mudah. }\end{array}$ & 10 & 21 & 1 & 0 & 32 & $82 \%$ & 82 & $\begin{array}{l}\text { Sangat } \\
\text { Tinggi }\end{array}$ \\
\hline 7 & $\begin{array}{l}\text { Saya tertarik untuk } \\
\text { memperhatikan } \\
\text { teknik-teknik yang } \\
\text { dijelaskan dalam } \\
\text { strategi kebugaran. }\end{array}$ & 13 & 19 & 0 & 0 & 32 & $85,2 \%$ & 85.2 & $\begin{array}{l}\text { Sangat } \\
\text { Tinggi }\end{array}$ \\
\hline 8 & $\begin{array}{l}\text { Strategi } \\
\text { kebugaran jasmani } \\
\text { menarik bagi saya. }\end{array}$ & 15 & 17 & 0 & 0 & 32 & $87 \%$ & 87 & $\begin{array}{l}\text { Sangat } \\
\text { Tinggi }\end{array}$ \\
\hline 9 & 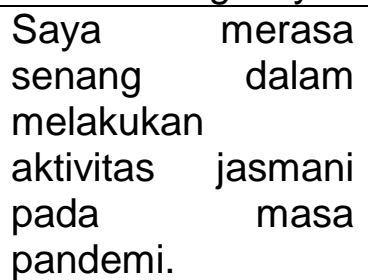 & 10 & 21 & 1 & 0 & 32 & $82 \%$ & 82 & $\begin{array}{l}\text { Sangat } \\
\text { Tinggi }\end{array}$ \\
\hline 10 & $\begin{array}{lr}\text { Saya tidak } & \text { merasa } \\
\text { senang } & \text { dengan } \\
\text { aktivitas } & \text { jasmani } \\
\text { yang } & \text { sulit } \\
\text { dilakukan. } & \\
\end{array}$ & 2 & 26 & 3 & 1 & 32 & $73 \%$ & 73 & $\begin{array}{l}\text { Sangat } \\
\text { Tinggi }\end{array}$ \\
\hline 11 & $\begin{array}{lr}\text { Saya melakukan } \\
\text { aktivitas jasmani } \\
\text { dengan sarana } \\
\text { yang memadai }\end{array}$ & 9 & 22 & 1 & 0 & 32 & $81 \%$ & 81 & $\begin{array}{l}\text { Sangat } \\
\text { Tinggi }\end{array}$ \\
\hline 12 & $\begin{array}{l}\text { Sarana yang ada } \\
\text { tidak membantu } \\
\text { dengan baik dalam } \\
\text { melakukan } \\
\text { aktivitas gerak. }\end{array}$ & 3 & 25 & 2 & 2 & 32 & $73 \%$ & 73 & $\begin{array}{l}\text { Sangat } \\
\text { Tinggi }\end{array}$ \\
\hline 13 & $\begin{array}{l}\text { Aktivitas gerak } \\
\text { yang diberikan } \\
\text { oleh pelatih sangat } \\
\text { membantu dalam } \\
\text { menjaga } \\
\text { kebugaran }\end{array}$ & 13 & 19 & 0 & 0 & 32 & $85 \%$ & 85 & $\begin{array}{l}\text { Sangat } \\
\text { Tinggi }\end{array}$ \\
\hline 14 & $\begin{array}{lr}\text { Gerakan-gerakan } \\
\text { sangat } & \text { mudah } \\
\text { untuk dilakukan }\end{array}$ & 13 & 19 & 0 & 0 & 32 & $85 \%$ & 85 & $\begin{array}{l}\text { Sangat } \\
\text { Tinggi }\end{array}$ \\
\hline
\end{tabular}


Jurnal Ilmu Keolahragaan Undiksha

p-ISSN : 2613-9693 | e-ISSN : 2613-9685

Volume 8 Nomor 1 Tahun 2020

\begin{tabular}{|c|c|c|c|c|c|c|c|c|c|}
\hline \multirow[t]{2}{*}{ No } & \multirow[t]{2}{*}{ Pernyataan } & \multicolumn{3}{|c|}{$\begin{array}{l}\text { Tanggapan } \\
\text { Responden }\end{array}$} & \multirow{2}{*}{$\begin{array}{l}\mathbf{N} \\
\text { STS }\end{array}$} & \multirow[t]{2}{*}{$\begin{array}{l}\text { Rata- } \\
\text { Rata }\end{array}$} & \multirow[t]{2}{*}{ Persentase } & \multicolumn{2}{|c|}{ Kategori } \\
\hline & & SS & $\mathbf{S}$ & TS & & & & & \\
\hline & dan efektif & & & & & & & & \\
\hline 15 & $\begin{array}{l}\text { Pelatih yang selalu } \\
\text { memberikan } \\
\text { motivasi membuat } \\
\text { saya berminat } \\
\text { melakukan } \\
\text { aktivitas jasmani. }\end{array}$ & 15 & 17 & 0 & 0 & 32 & $87 \%$ & 87 & $\begin{array}{l}\text { Sangat } \\
\text { Tinggi }\end{array}$ \\
\hline 16 & $\begin{array}{l}\text { Pelatih selalu } \\
\text { menanamkan } \\
\text { sikap disiplin ketika } \\
\text { melakukan } \\
\text { kegiatan yang } \\
\text { berhubungan } \\
\text { dengan aktivitas } \\
\text { jasmani. }\end{array}$ & 13 & 19 & 0 & 0 & 32 & $85 \%$ & 85 & $\begin{array}{l}\text { Sangat } \\
\text { Tinggi }\end{array}$ \\
\hline 17 & $\begin{array}{ll}\text { Saya } & \text { tidak } \\
\text { mengetahui } & \\
\text { manfaat } & \text { dari } \\
\text { kebugaran } & \\
\text { jasmani. } & \end{array}$ & 6 & 23 & 1 & 2 & 32 & $76 \%$ & 76 & $\begin{array}{l}\text { Sangat } \\
\text { Tinggi }\end{array}$ \\
\hline 18 & $\begin{array}{l}\text { Saya lebih mudah } \\
\text { menjaga } \\
\text { kebugaran jasmani } \\
\text { dengan dibantu } \\
\text { oleh pelatih }\end{array}$ & 10 & 19 & 2 & 1 & 32 & $80 \%$ & 80 & $\begin{array}{l}\text { Sangat } \\
\text { Tinggi }\end{array}$ \\
\hline 19 & $\begin{array}{l}\text { Ajakan teman- } \\
\text { teman dekat saya } \\
\text { membuat saya } \\
\text { berminat mengikuti } \\
\text { aktivitas jasmani. }\end{array}$ & 9 & 16 & 6 & 1 & 32 & $76 \%$ & 76 & $\begin{array}{l}\text { Sangat } \\
\text { Tinggi }\end{array}$ \\
\hline 20 & $\begin{array}{l}\text { Aktivitas jasmani } \\
\text { membuat saya } \\
\text { memperluas } \\
\text { pergaulan positif } \\
\text { sehingga saya }\end{array}$ & 16 & 16 & 0 & 0 & 32 & $88 \%$ & 88 & $\begin{array}{l}\text { Sangat } \\
\text { Tinggi }\end{array}$ \\
\hline
\end{tabular}

Dari hasil analisis 10 pernyataan motivasi intrinsik bila dirata-ratakan memperoleh rata-rata skor $83 \%$ sedangkan hasil analisis 10 pernyataan motivasi ekstrinsik bila di rata-ratakan memperoleh skor $81 \%$. Berdasarkan ratarata skor yang diperoleh pada setiap komponen indikator motivasi yang dibagi menjadi indikator motivasi intrinsik dan indikator motivasi ekstrintik dari 32 orang sebagai sample dalam penelitian memperoleh rata-rata motivasi sebagai berikut. 
Tabel 3. Hasil analisis deskriptif

\begin{tabular}{ccccc}
\hline No. & Indikator & Banyak siswa & Rata-rata & Katagori \\
\hline 1. & Faktor Instrinsik & 32 & 83 & Sangat Tinggi \\
2. & Faktor Ekstrinsik & 32 & 81 & Sangat Tinggi \\
\hline
\end{tabular}

Rumus :

$$
\begin{aligned}
& \frac{\bar{X} 1+\bar{X} 2}{2} \\
= & \frac{83+81}{2} \\
= & 82 \%
\end{aligned}
$$

Berdasarkan kedua indikator pada variabel Motivasi Atlet Club Renang di Kabupaten Badung diperoleh rata-rata skor 82, bila dikonversikan ke dalam tabel interval kategori berapa pada katagori sangat tinggi

\section{PENUTUP \\ Simpulan}

Adapun kesimpulan dari hasil analisis data menggunakan deskriptif kuantitaif motivasi atlet club renang di kabupaten Badung dalam menjaga kebugaran jasmani pada masa pandemi covid-19 berada katagori sangat tinggi.

Aritianto, Andri. 2015. Pengaruh Pengembangan Pembelajaran Renang Gaya Dada Terhadap Keterampilan Renang Gaya Dada (Studi Pada Siswa Ekstrakurikuler Renang Smp Santa Maria Surabaya). Jurnal Pendidikan Olahraga Dan Kesehatan Volume 03 Nomor 02 Tahun 2015.

Baskoro, Firza Yoga. 2018. Pemanasan Fisik Menurunkan Kejadian Kram Otot Triceps Surae pada Atlet Renang Physical Heating Reduces Genesis of Triceps Surae Muscle Cramps in Swimming Athletes. Jurnal Universitas Muhammadiyah

\section{Saran}

Berdasarkan kesimpulan penelitian di atas, adapun saran yang dapat diberikan adalah sebagai berikut :

Saran kepada atlet renang dari hasil survey agar menjadi lebih termotivasi dalam menjaga kebugaran jasmani meskipun ditengah pandemi harus berusaha mencari untuk meningkatkan kebugaran jasmani. Saran kepada peneliti lain yang berminat mengadakan penelitian lebih lanjut mengenai survey motivasi atlet renang dalam menjaga kebugaran jasmani pada masa pandemi covid-19 menjadikan hasil penelitian ini sebagai salah satu referensi untuk meneliti dalam ruang lingkup yang lebih luas, sehingga diperoleh sumbangan ilmu yang yang lebih baik dan sesuai dengan perkembangan zaman dan diperoleh dalam penelitian objektif.

\section{DAFTAR PUSTAKA}

Semarang Vol. 2 No.4Februari 2018.

Ishak, Muchamad. 2018. Pengaruh Aktivitas Pembelajaran Renang Gaya Dada Terhadap Pembentukan Daya Tahan. Jurnal Sains Keolahragaan \& Kesehatan Vol. III, No. 1, Juni, 2018.

Nurkholis. 2013. Pendidikan Dalam Upaya Memajukan Teknologi. Jurnal Kependidikan, Vol. 1 No. 1 Nopember 2013.

Priana. 2019. Pengaruh Alat Bantu Latihan Pull Buoy Terhadap Prestasi Renang Gaya Dada. 
Journal of S.P.O.R.T, Vol. 3, No.1, Mei 2019.

Prasetyo, Edo.2017. Hubungan antara Frekuensi Gerakan Kaki dengan Prestasi Renang Gaya Crawl 50 Meter. Indonesia Performance Journal 1 (2) (2017).

Malik, Abdul. 2015. Perbedaan Hasil Belajar Renang Gaya Bebas Antara Metode Bagian Dengan Metode Keseluruhan Pada Mahasiswa Penjaskesrek Fkip Unsyiah Angkatan 2010. Jurnal IImiah Mahasiswa Pendidikan Jasmani, Kesehatan dan Rekreasi Fakultas Keguruan dan IImu Pendidikan Unsyiah Volume 1, Nomor 1: 54 63 Februari 2015.
Rubiansyah, Aziz. 2016. Pengaruh Latihan Plyometrics Terhadap Hasil Tolakan Start Pada Olahraga Renang. Jurnal Terapan IImu Keolahragaan 2016 Vol.01 No.01.

Sunandarti, Hermi. 2017. Mekanika Gaya Apung Pada Olahraga Renang. Jurnal IImiah Pendidikan Jasmani, 1 (1) 2017.

Wicaksono, Deni Setyo. 2017. Kontribusi Kecepatan Gerakan Tangan Dan Gerakan Kaki Terhadap Kecepatan Renang Gaya Bebas 25 Meter (Studi Pada Siswa Smp Hang Tua 5 Yang Mengikuti Ekstrakurikuler Renang). Jurnal Pendidikan Olahraga dan Kesehatan Volume 05 Nomor 03 Tahun 2017. 